DOI: $10.2478 / \mathrm{v} 10047-012-0023-3$

\title{
INFLUENCE OF LASER CLADDING PARAMETERS ON THE DISTRIBUTION OF ELEMENTS IN THE BEADS OF NICKEL-BASED Ni-Cr-B-Si ALLOY
}

\author{
O.G. Devoyno ${ }^{1}$, P.S. Drozdov ${ }^{2}$, Y.B. Dovoretskiy ${ }^{2}$, \\ M.A. Kardapolova ${ }^{1}$, N.I. Lutsko ${ }^{1}$, E. Tamanis ${ }^{2}$ \\ ${ }^{1}$ Belarusian National Technical University, \\ 65 Nezavisimosty Ave, Minsk, BELARUS \\ ${ }^{2}$ Daugavpils University, \\ 13 Vienības Str, Daugavpils, LATVIA
}

\begin{abstract}
The authors explore the beads obtained by laser cladding with nickel-based self-fluxing alloy (grain size $20-80 \mu \mathrm{m}$ ) at different laser beam travel rates against the sample and different cladding distances. They examined the iron, nickel, chrome and silicon content of the coating in dependence on the cladding rate and the microstructure in each zone of a bead. As a result, it was established that the beads after laser cladding have a similar structure morphology in all the examined zones, which confirms that there is intense mixing of the molten-metal pool. A distinct correlation has been found between the distribution of coating elements and the modes of laser cladding: the nickel, chrome, and silicon contents of the coating are decreasing while the iron content is increasing with increased cladding rate. The authors point out a strong effect of radiation shielding caused by the vapours generated during the process of melting the powder particles in the area exposed to laser radiation.

Key words: laser cladding, self-fluxing alloy, distribution of elements, structure morphology, laser processing parameters, position of the focus against the sample, alloy grains.
\end{abstract}

\section{INTRODUCTION}

Modern production requires development of resource-saving technologies [1]. A limiting factor in the manufacturing of many products is the time needed to design and fabricate all types of moulds and dies. Die equipment is the most labour-consuming, which determines its high cost. A great progress is observed in the methods of rapid prototyping (RP) and rapid tooling (RT), which expand the concept of making new components (called rapid manufacturing (RM)). These methods are designed to assist in the process of preparation of a new product by its visualisation directly from the computer-aided design (CAD) database and further manufacturing of this product by direct material deposition using lasers [2].

Today many manufacturers are extensively looking for technologies able to fabricate various parts directly from a CAD drawing with reproduction of the constructed micro- and macrostructure. Even today, some of these technologies can be applied successfully in manufacturing, repairing, and refurbishing the machine components [3]. 
The latest developments in direct metal deposition (DMD) by the University of Michigan, the light engineered net shaping (LENS) by Sandia National Laboratories, and the direct light fabrication (DLF) by Los Alamos National Laboratory have demonstrated that near-full density $3 \mathrm{D}$ objects can be fabricated directly from the CAD database with the features equivalent to those acquired in a process of plastic deformation. These and a number of other similar technologies are already potentially available for direct manufacturing of components and dies [4-9].

In all above technologies the method of laser cladding is used for direct metal deposition. Laser cladding is a technology for the formation of coating, which includes deposition of different materials on a metal substrate using laser beam as a source of energy [10-13]. This is a flexible technology, which allows deposition of powder delivered by a carrier gas to the molten pool generated by laser radiation on the surface of substrate. Depending on the position of the powder feeding unit against the axis of the laser beam the delivery of powder can be coaxial or lateral. This technology can be used both to harden new surfaces and to refurbish the worn or damaged surfaces.

Traditional cladding technologies, such as argon arc cladding using filler metal, semiautomatic arc cladding in carbon dioxide, and plasma jet cladding, are characterised by a high thermal impact on components, resulting in re-crystallisation and annealing of the substrate material. As contrasted to these methods, heat transfer in laser cladding with a laser beam $0.5-3 \mathrm{~mm}$ in diameter takes place in a bounded region. As a result, the heat-affected zone (HAZ) is limited to several millimetres. Therefore, the heat stress zone is also small, the deformations are minimal, and the mechanical properties of the substrate are almost unaffected. Comparative characteristics of traditional cladding technologies are tabulated below.

Table 1

Characteristics of traditional cladding technologies

\begin{tabular}{|l|c|c|c|c|}
\hline \multicolumn{1}{|c|}{ Parameter } & $\begin{array}{c}\text { Argon arc } \\
\text { cladding with } \\
\text { filler metal }\end{array}$ & $\begin{array}{c}\text { Semiautomatic } \\
\text { arc wire } \\
\text { cladding in } \mathrm{CO}_{2}\end{array}$ & $\begin{array}{c}\text { Plasma } \\
\text { cladding }\end{array}$ & $\begin{array}{c}\text { Laser } \\
\text { cladding }\end{array}$ \\
\hline Layer thickness, $\mathrm{mm}$ & $0.5 \ldots 3.0$ & $1 \ldots 6$ & $1 \ldots 5$ & $0.2 \ldots 2$ \\
\hline Deposition rate, $\mathrm{kg} / \mathrm{h}$ & $0.5 \ldots 3.5$ & $2.3 \ldots 11$ & $2.5 \ldots 6.5$ & $0.2 \ldots 7$ \\
\hline Deformations & Gross & Medium & Medium & Minor \\
\hline Dispersion coefficient* $\%$ & $10 \ldots 20$ & $15 \ldots 20$ & Medium & $1 \ldots 5$ \\
\hline
\end{tabular}

* Percentage of substrate material in the bead.

Therefore, laser cladding is a very promising method of coating deposition. Several interrelated processes take place in the zone of laser cladding: melting of substrate material under the influence of laser radiation with generation of a molten pool; melting of powder in the molten pool with the formation of a bead; and laser radiation shielding by vapours of the substrate material influencing the first two processes. All the above processes together determine the quality of coatings characterised by such parameters as the microstructure, the distribution of microhardness, and the coating composition. 
The last named parameter is especially important for the investigation, as multicomponent materials with a complex composition undergoing deep changes in the process of cladding are used to provide high physical and mechanical properties of coatings. Data on the effect of laser cladding modes on the composition of a coating allow prognosis of the cladding results and the properties of the deposited layer.

In this work, we investigate the actual distribution of elements in the beads of self-fluxing nickel-based alloy in the process of laser cladding.

\section{EXPERIMENTAL CONDITIONS AND PROCEDURE}

In the investigation, we used a technological laser complex including a carbon dioxide continuous wave laser ("Комета 2", radiation power $1000 \mathrm{~W}$ ) and a coordinate system providing the necessary laser beam travel against the samples. The cladding chart is shown in Fig. 1.

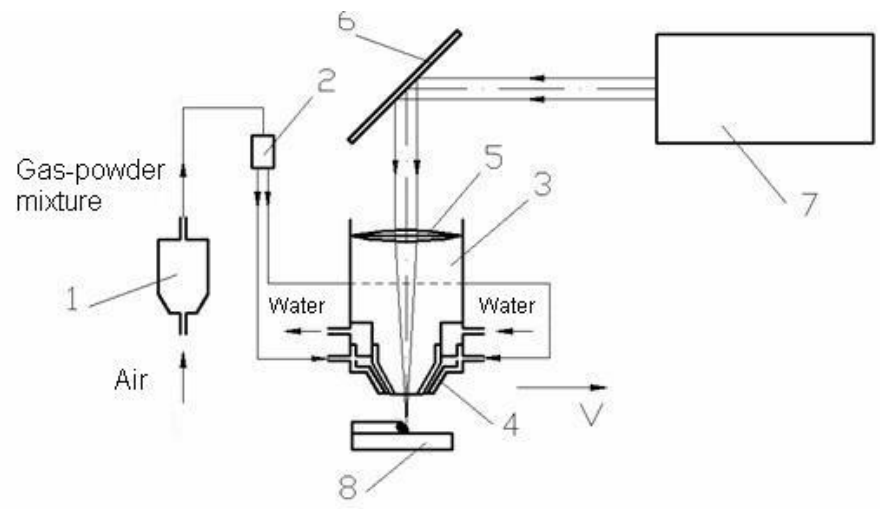

Fig. 1. Laser cladding chart.

The sample (8) was positioned on the surface of a coordinate system table, which provided the travel of deposition head-lens (3) with a coaxial deposition nozzle (4), focusing lens (5) and swivel mirrors (6) against the sample at a set cladding rate. The deposition material was mixed with air in the feeder (1), and, in the form of a gas-powder mixture delivered to the distributor (2) and further to the coaxial nozzle (4) via four pipes. The laser beam (7) was directed to the surface of the sample through the system of swivel mirrors (6) and the lens (5) with a focal distance of $109 \mathrm{~mm}$. The focus of the powder flow fed through the sloping channels of the coaxial nozzle (4) coincided with the focus of laser radiation, i.e. was positioned at a distance of $12 \mathrm{~mm}$ from the face of the nozzle. Laser cladding was performed at a laser radiation power of $1000 \mathrm{~W}$, the powder feed rate was $18 \mathrm{~g} / \mathrm{min}$, and the cladding rate varied from 40 to $120 \mathrm{~mm} / \mathrm{min}$. The cladding distance determining the position of the laser beam focus against the surface of the sample varied from 10 to $14 \mathrm{~mm}$. Correlation of the position of the laser beam focus and the cladding distance is shown in Table 2. Single beads were deposited in each case. Cladding was performed for samples made of steel 45 and having the dimensions of $25 \times 25 \times 8 \mathrm{~mm}$. As deposition material, the self-fluxing nickel-based $\mathrm{Ni}-\mathrm{Cr}-\mathrm{B}-\mathrm{Si}$ alloy with $20-80 \mu \mathrm{m}$ granulation was used. 
Correlation of the laser beam focus position and the cladding distance

\begin{tabular}{|c|l|}
\hline Cladding distance $\mathrm{L}, \mathrm{mm}$ & \multicolumn{1}{c|}{$\begin{array}{c}\text { Position of the laser beam focus against } \\
\text { the surface of the sample }\end{array}$} \\
\hline 10 & $\begin{array}{l}-2 \text { mm below the surface of the sample } \\
\text { (defocused beam) }\end{array}$ \\
\hline 12 & $\begin{array}{l}\text { 0 mm, on the surface of the sample } \\
\text { (focused beam) }\end{array}$ \\
\hline 14 & $\begin{array}{l}+2 \mathrm{~mm} \text { over the surface of the sample } \\
\text { (defocused beam) }\end{array}$ \\
\hline
\end{tabular}

Visual examination of the deposited samples has shown that in the investigated range of modes no pores or cracks were present in the border region of the deposition and substrate.

Distribution of elements was determined on the cross-sections of beads using an EDX detector INCA Synergy (Oxford Instruments), and the microstructure shots were made with a metallographic microscope МИКРО 200 with video capture. The zones examined on each cross-section of the bead in order to determine the distribution of elements are shown in Fig. 2.

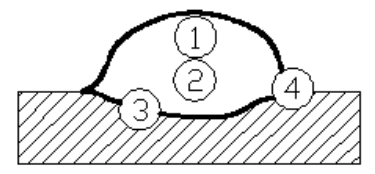

Fig. 2. Zones examined on the cross-sections of the beads.

The dependences between the iron, nickel, chrome, and silicon content of the coatings and the cladding rates at different cladding distances were obtained for each zone of the bead (Figs. 3-10). The microstructures in the examined zones are shown in Figs. 11, 12.

\section{ANALYSIS OF THE FINDINGS}

As is seen from the data presented, the highest content of nickel (Figs. 3 and 7), chrome (Figs. 4 and 8), and silicon (Figs. 5 and 9) in the coating are observed at the cladding distance $\mathrm{L}=14 \mathrm{~mm}$ (defocused beam, the beam focus over the surface of the substrate) for all examined zones of the bead, i.e. in the cases when remelting of the substrate is minimal. The lowest nickel, chrome, and silicon content of the coating appears to be at the cladding distance $\mathrm{L}=12 \mathrm{~mm}$ (the beam focus on the surface of substrate) also for all zones of the bead, which could be indicative of remelting of the substrate surface, when some proportion of these elements is transferred from the coating to the substrate. Reduction in the content of nickel, chrome, and silicon is observed upon the increase in the cladding rate; while it would be expected that the degree of substrate remelting and the subtraction of the above elements from the coating should be reduced. Most likely, this is determined by the shielding effect produced by vapours generated during the melting of powder particles in the zone exposed to laser radiation [14-16]. At a low scanning rate the evaporation is more intensive, shielding is strong enough, 
and nickel, chrome, and silicon are less transferable to the substrate. At a higher scanning rate, the evaporation is reduced noticeably, the shielding is minor, and the abovementioned elements are intensively transferred to the substrate. It could also be noted that the chrome content of the coating decreases moderately upon the increase of the cladding rate, while this occurrence is applicable to silicon to a greater extent. Obviously, this fact is directly connected with a higher chemical activity of silicon as compared to chrome.

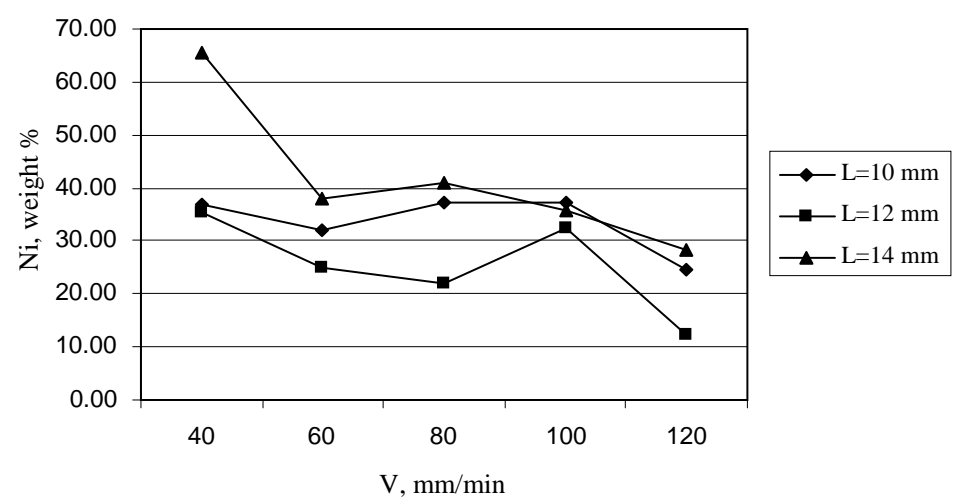

Fig. 3. Nickel content, weight $\%$,

in zone 3 (coating) at different cladding rates $\mathrm{V}$ and distances $\mathrm{L}$.

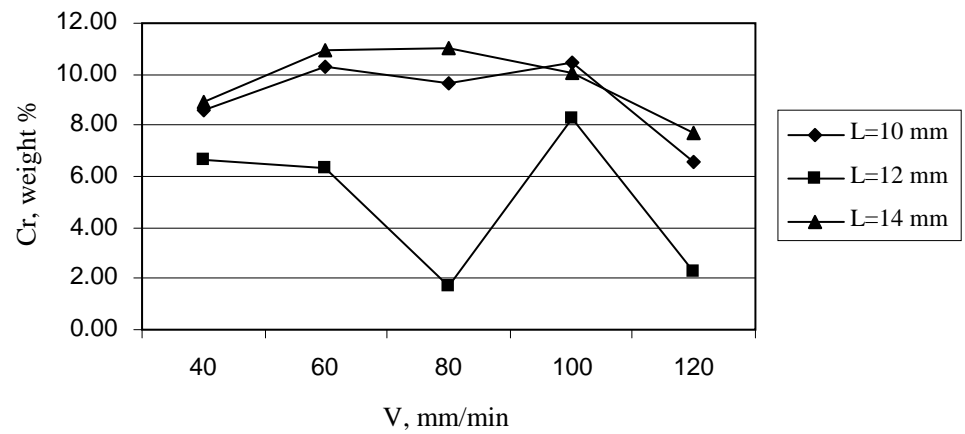

Fig. 4. Chrome content, weight \%,

in zone 3 (coating) at different cladding rates $\mathrm{V}$ and distances $\mathrm{L}$.

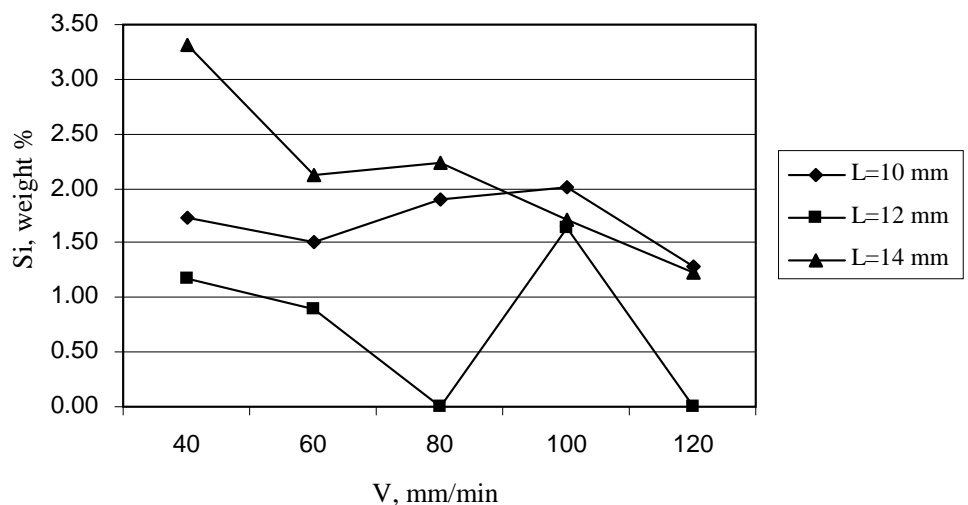

Fig. 5. Silicon content, weight $\%$,

in zone 3 (coating) at different cladding rates $\mathrm{V}$ and distances $\mathrm{L}$. 


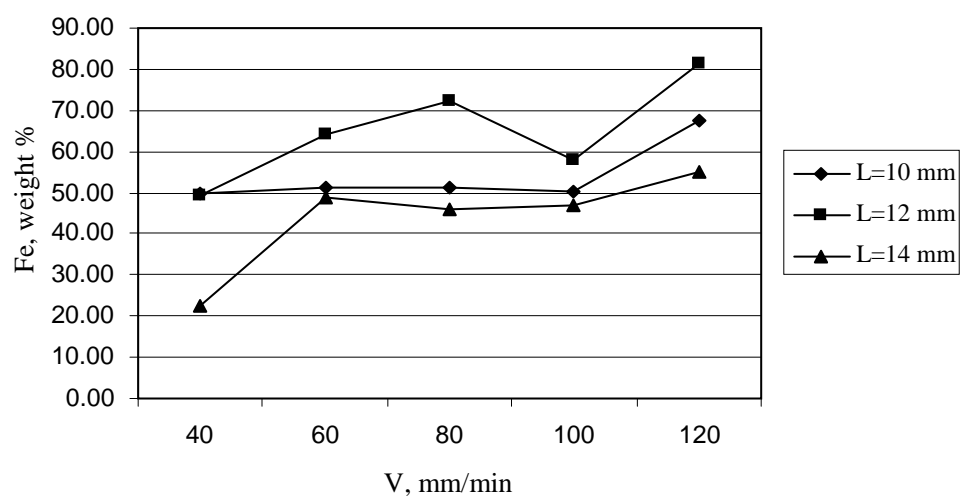

Fig. 6. Iron content, weight $\%$,

in zone 3 (coating) at different cladding rates $\mathrm{V}$ and distances $\mathrm{L}$.

In the process of deposition a ferritization of the obtained coating material takes place. The iron content of coating (Figs. 6 and 10) for all zones of the beads is minimal at the distance $\mathrm{L}=14 \mathrm{~mm}$ (defocused beam, the beam focus over the surface of the substrate), which corresponds to the least remelting of the substrate in this case. The highest iron content of coating is observed at the distance $\mathrm{L}=12 \mathrm{~mm}$ (the beam focus on the surface of substrate), i.e. when the greatest substrate remelting and the mutual mixing of coating and substrate occur. In this case the degree of remelting is quite high, as the iron content in the coating may reach $70 \mathrm{wt} \%$, while the nickel content falls to $20 \mathrm{wt} \%$ (the nickel content of the source powder amounts approx. to $70 \mathrm{wt} \%$ and the iron content to 3-4 wt \%).

The iron content of coating increases upon the increase in the cladding rate in all the cases, while the opposite would be expected due to the reduced input energy. Here the effect of radiation shielding by vapours of coating material probably manifests itself, since these vapours produce a stronger shielding of the type at a low cladding rate and less iron is transferred to the coating. At a higher cladding rate less vapours are produced, the shielding is weak, and more iron is transferred to the coating.

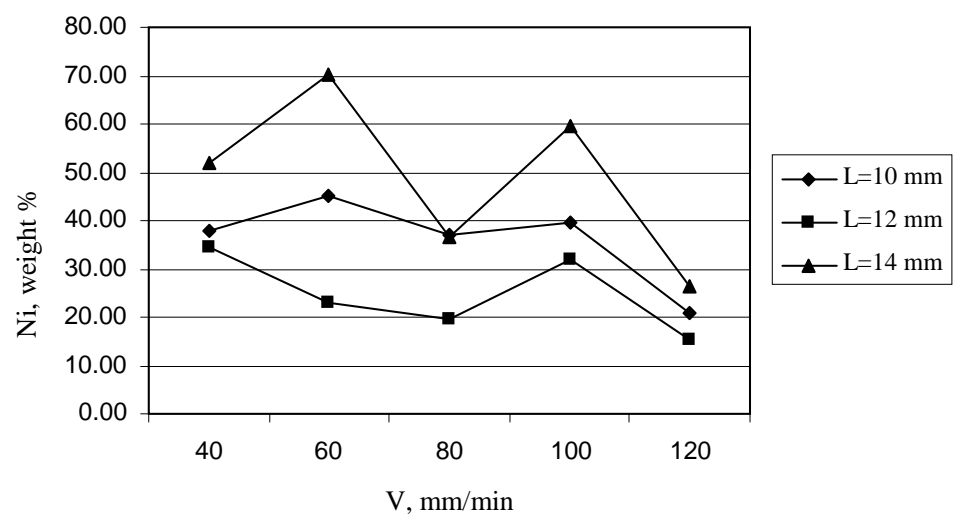

Fig. 7. Nickel content, weight $\%$,

in zone 1 (coating) at different cladding rates $\mathrm{V}$ and distances $\mathrm{L}$. 


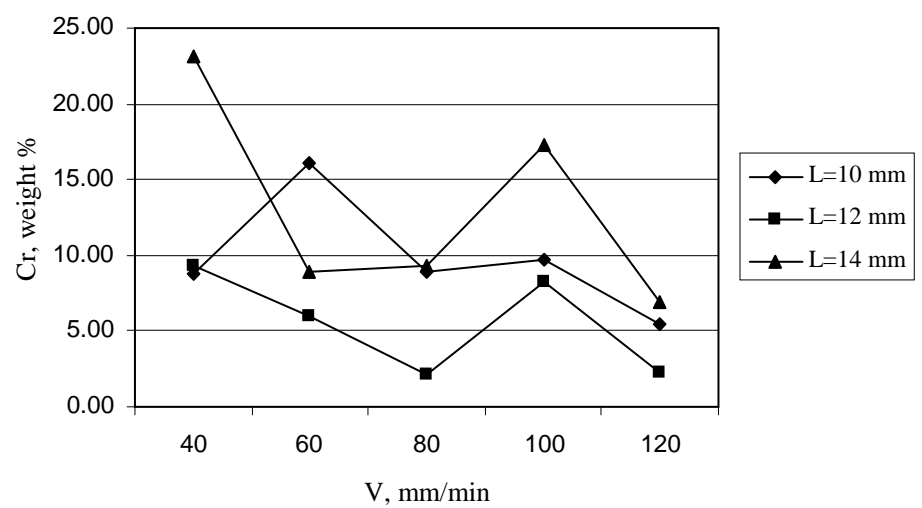

Fig. 8. Chrome content, weight $\%$,

in zone 1 (coating) at different cladding rates $\mathrm{V}$ and distances $\mathrm{L}$.

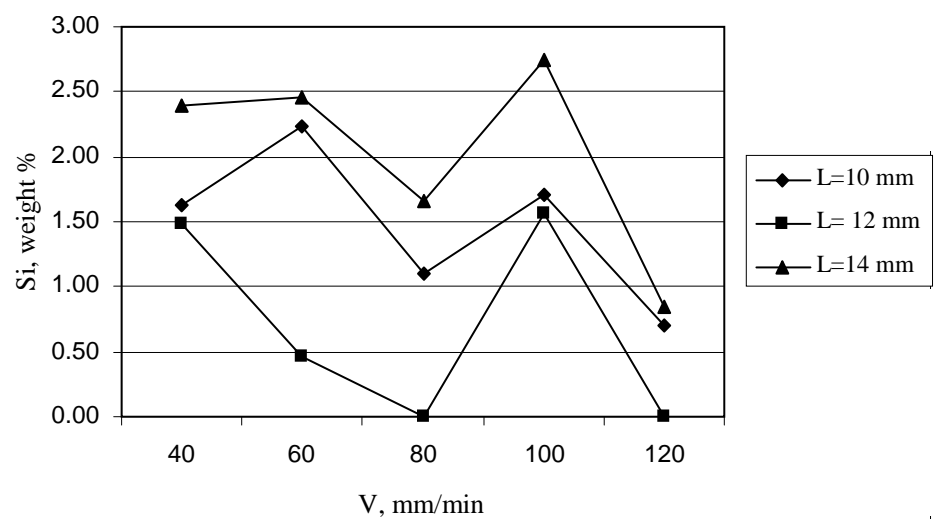

Fig. 9. Silicon content, weight $\%$,

in zone 1 (coating) at different cladding rates $\mathrm{V}$ and distances $\mathrm{L}$.

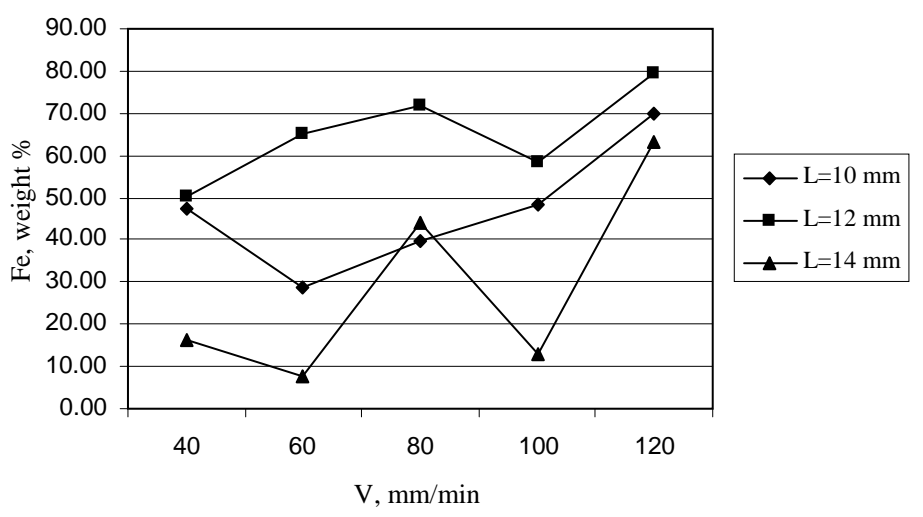

Fig. 10. Iron content, weight $\%$,

in zone 1 (coating) at different cladding rates $\mathrm{V}$ and distances $\mathrm{L}$.

Comparing the dependences of the elemental content of coating on the technological modes of laser cladding in different zones of the beads it can be noted that there are no any substantial differences between them. This fact suggests that the temperature in the bead due to its comparability in size with the laser spot diameter is most likely distributed quite evenly across its volume, and the mixing 
effect takes course identically in different zones. This fact is supported in general also by the provided photos (Figs. 11, 12) showing microstructures of the coating in different zones, which virtually do not differ: the bead has a dense structure with distinct constituents.

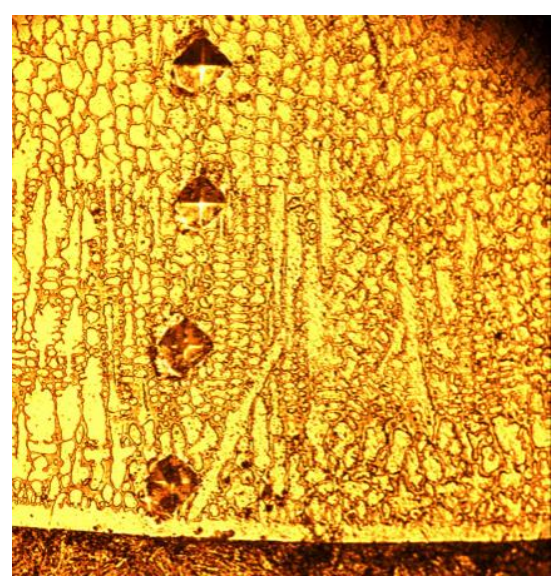

Fig. 11. Microstructure of nickel-based Ni-Cr-B-Si alloy after laser cladding at $\mathrm{V}=80 \mathrm{~mm} / \mathrm{min}$ and $\mathrm{L}=12 \mathrm{~mm}$ in zone 3 (x 980).

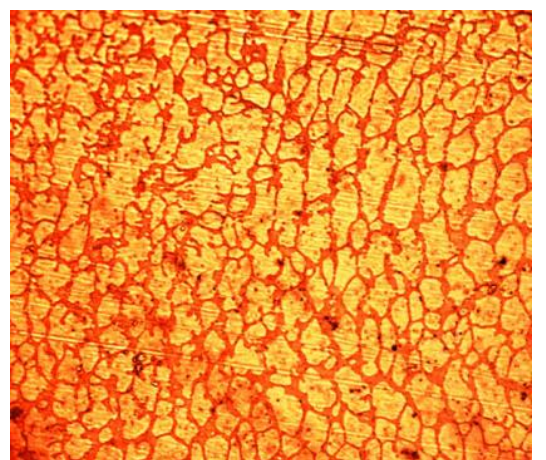

Fig. 12. Microstructure of nickel-based Ni-Cr-B-Si alloy after laser cladding at $\mathrm{V}=100 \mathrm{~mm} / \mathrm{min}$ and $\mathrm{L}=10 \mathrm{~mm}$ in zone 1 (x 980).

Content of elements in the source powder of nickel-based $\mathrm{Ni}-\mathrm{Cr}-\mathrm{B}-\mathrm{Si}$ alloy, deposited material, and steel 45

\begin{tabular}{|l|c|c|c|c|c|c|}
\hline & $\mathrm{Fe}$ & $\mathrm{C}$ & $\mathrm{Si}$ & $\mathrm{Cr}$ & $\mathrm{B}$ & $\mathrm{Ni}$ \\
\hline $\begin{array}{l}\text { Element content, weight \%, in } \\
\text { steel 45 ГOCT 1050-74 }\end{array}$ & $\begin{array}{c}\text { Substrate } \\
\sim 97.8\end{array}$ & $\begin{array}{c}0.42- \\
0.5\end{array}$ & $\begin{array}{c}0.17- \\
0.37\end{array}$ & 0.25 & - & 0.25 \\
\hline $\begin{array}{l}\text { Element content in zone 1 } \\
\text { (substrate) of the bead }\end{array}$ & 93.12 & 4.36 & 0.55 & 0.82 & - & 1.15 \\
\hline $\begin{array}{l}\text { Element content in zone 1 } \\
\text { (coating) of the bead }\end{array}$ & 49.61 & 3.39 & 1.74 & 8.57 & - & 36.68 \\
\hline $\begin{array}{l}\text { Element content in the source } \\
\text { powder of nickel-based alloy } \\
\text { Ni-Cr-B-Si, } \\
\text { Ty-48-4206-158-82 }\end{array}$ & $3-4$ & $0.6-1$ & $4-4.5$ & $14-20$ & $\begin{array}{c}2.8- \\
3.4\end{array}$ & $\begin{array}{c}\text { Substrate } \\
\sim 70\end{array}$ \\
\hline
\end{tabular}


Mutual transfer of the coating and substrate materials mentioned above is especially evident if we compare the content of elements in steel 45 , ГОСТ 105070, nickel-based alloy $\mathrm{Ni}-\mathrm{Cr}-\mathrm{B}-\mathrm{Si}$, TY $48-4206-158-82$ as well as in boundary regions of the coating and substrate in zone 1 of the bead (see Table 3 ).

\section{CONCLUSIONS}

Thus, the results obtained show the following:

- in the beads produced by the method of laser cladding of self-fluxing nickelbased $\mathrm{Ni}-\mathrm{Cr}-\mathrm{B}-\mathrm{Si}$ alloy the morphology of structure in all examined areas is of similar nature, which points to an intense mixing of the liquid melt pool;

- a distinct dependence on the laser cladding modes is observed for the distribution of coating elements;

- the nickel, chrome, and silicon content of the coating decreases while the iron content increases at increasing the cladding rate; also, a strong effect of radiation shielding takes place, which is caused by the vapours generated during the process of melting the powder particles in the area exposed to laser radiation. As a result, at a low cladding rate, when evaporation is more intensive, nickel, chrome, and silicon are less transferred to the substrate and iron less penetrates into the coating. At a high cladding rate when evaporation is reduced considerably, the opposite effect is observed;

- the greatest transfer of elements from the substrate to the coating and, vice versa, from the coating to the substrate, is observed at a cladding distance of $12 \mathrm{~mm}$, when the focus of laser beam is on the surface of substrate, and the least transfer is observed at a cladding distance of $14 \mathrm{~mm}$, when the focus is positioned above the surface of the substrate;

- all the patterns equally apply to all examined areas of the beads, showing even temperature distribution along the section of the bead obtained by laser cladding and similar processes of mixing in all these areas.

\section{REFERENCES}

1. Mazumder, J., Dutta, D., Ghosh, A., \& Kikuchi, N. (2003). Designed materials: what and how. Proceedings of the SPIE, 4831, 505- 516.

2. Wohlers, T. (2003). Wohlers Report - Rapid Prototyping. Tooling \& Manufacturing State of the Industry, Wohlers Associates Inc., Colorado (USA).

3. Malin, V., Jonson, R.N., \& Sciammarelia, F. (2005). Laser cladding helps refurbish US Navy ship components. The AMPTIAC Quarterly, 8(3), 3-9.

4. Koch, J, \& Mazumder, J. (1993). Rapid prototyping by laser cladding (ed-s: P.Denney, I. Miyamoto, BL Mordike). Proceedings of ICALEO' 93, 77, 556-65.

5. Mazumder, J., Koch, J., Nagarathnam, K., \& Choi, J. (1996). Rapid manufacturing by laser aided direct deposition of metals. (ed-s: T.M. Cadle, K.S. Narasimhan). In: Advances in powder metallurgy and particulate materials, part 15. Princeton, NJ, Metal Powders Industries Federation (MPIF), 107-18.

6. Mazumder, J., Choi, J., Nagarathnam, K., Koch, J., \& Hetzner, D. (1997). Direct Metal Deposition (DMD) of H13 tool steel for 3-D components: microstructure and mechanical properties. J. Metals, 49(5), 55-60.

7. Mazumder, J., Schifferer, A., \& Choi, J. (1999). Direct materials deposition: designed macro and microstructure. Mater. Res. Innova, 3, 118-31. 
8. Keicher, D.M., \& Smugersky, J.E. (1997). The laser forming of metallic components using particulate materials. J. Metals, 49 (5), 51-54.

9. Milewski, J.O, Lewis, G.K., Thoma, D.J. et al (1997). Directed light fabrication of a solid metal hemisphere using 5-axis powder deposition. J. Mater. Process Tech., 75(13), 165-72.

10. John, C. (2005). Laser Processing of Engineering Materials: Principles, Procedure and Industrial application. Elsevier Butterworth - Heintmann, Burlington, MA (USA).

11. William, M. Steen. (2003). Laser Material Processing, $3^{\text {rd }}$ ed-n. London: Springer.

12. Toyserkani, E., Khajepour, A.,\& Corbin, S. (2005). Laser Cladding. Boca Raton (Florida): CRS Press.

13. De Hosson, J.Th.M., \& Ocelic, V. (2003). Functionally graded materials produced with high power lasers. In: Proceedings of ASTRA, 368-376. Hyderabad (India).

14. Liu, C.Y., \& Lin, J. (2003). Thermal processes of a powder particle in coaxial laser cladding. Opt. Laser Technol., 35 (2), 81-86.

15. Wen, S.Y., Shin, Y.C., Murthy, J.Y., \& Sojka, P.E. (2009). Modeling of coaxial powder flow for the laser direct deposition process. Intern. Journal of Heat and Mass Transfer, 52, 5867-5877.

16. Zecovic, Srdja, Rajeev Dwvedi, \& Kovacevic, Radovan. (2007). Numerical simulation and experimental investigation of gas-powder flow from radially symmetrical nozzles in laser-based direct metal deposition. Intern. J. of Machine Tools \& Manufacture, 47, $112-123$.

\section{LĀZERUZKAUSĒŠANAS PARAMETRU IETEKME UZ ELEMENTU SADALĪJUMU UZKAUSĒTOS SAKAUSĒJUMA Ni-Cr-B-Si VELTNĪŠOS \\ O. Devoyno, P. Drozdovs, Y. Dovoretskiy, M. Kardapolova, N. Lutsko., E. Tamanis}

\section{Kopsavilkums}

Rakstā apskatīti uzkausējuma veltnīši, kas iegūti ar lāzeruzkausēšanas metodi no uz niḳeli bāzēta pašplūstoša sakausējuma pulvera ar graudu izmēru 20 $80 \mu \mathrm{m}$ ar dažādiem lāzera stara kustības ātrumiem un dažādiem uzkausēšanas garumiem.

Tika izpētìta dzelzs, niķeļa, hroma un silīcija satura atkarība no uzkausēšanas ātruma un mikrostruktūra dažādās uzkausējuma vietās katrai uzkausējuma zonai.

Konstatēts, ka uzkausējumu veltnīšiem ir līdzịga struktūras morfolog̣ija visās izpētītajās zonās, kas liecina par intensīvu šķidrā materiāla sajaukšanos kausējuma vannā. Novērota tieša korelācija starp pārklājuma materiālu sadalījumu un lāzeruzkausējuma režīmiem, t.i., niķeļa, hroma un silīiija saturs samazinās, un dzelzs saturs palielinās, pieaugot uzkausēšanas ātrumam. Tāpat arī novērots pārklājuma ekranēšanas ar tvaiku efekts, kas rodas pulvera dalıiņu kausēšanas laikā no lāzerapstarotā laukuma.

10.04.2012. 